JOAL, (JOURNAL, (DF APPIIEI) IINGUIS'ITCS ANI) II'TIRA'TURE)

Vol. 5 No. 2, 2020

ISSN (print): 2502-7816; ISSN (online): 2503-524X

Available online at https:/ / ejournal.unib.ac.id/index.php/joall/index

doi: http://dx.doi.org/10.33369/joall.v5i2.11139

\title{
MIND MAPPING: A WAY TO HONE EFL NINTH GRADERS' WRITING SKILL AT AN ISLAMIC BOARDING SCHOOL
}

\author{
Yelni Erniyati ${ }^{1}$ \\ Institut Agama Islam Negeri (IAIN) Kerinci ${ }^{1}$ \\ Corresponding email: yelnierniyati@rocketmail.com \\ Abstract \\ The purposes of this research were to reveal the teaching process by \\ using mind-mapping technique, and the students' writing ability. This \\ was classroom action research which took place at Islamic Boarding \\ School Al-Munawwaroh Bangko. The participants were ninth grade \\ students that consisted of 23 female students in the class. This research \\ was conducted in three cycles, and each cycle consisted of three \\ meetings. In collecting the data, the researcher employed observation, \\ field note, and tests. For the test, the researcher utilized writing test in \\ the third meeting of every cycle; students were asked to write or \\ compose the paragraph based on the given topic related to their mind \\ map. The result showed that the teaching and learning process by using \\ mind mapping was more interesting, and students were participated \\ more active than before. They are enthusiastic in recalling and \\ brainstorming the words related to the topic given. The data also \\ indicated that there are enhancements of students' writing after they \\ were taught using mind-mapping technique which could be seen from \\ the improvements of students' score from the preliminary data to the \\ final data. Consequently, mind mapping technique is highly \\ recommended in teaching and in improving students' writing.
}

Keywords: Mind mapping, writing skill, EFL ninth graders

\section{INTRODUCTION}

Based on syllabus of junior high school in School Based Curriculum, it is expected that the ninth grade students are able to express the meaning in short written functional text and simple essay in forms of procedure and report to interact with the surroundings. It means that after learning process of writing, the students can write procedure and report text. On the other hand, the fact revealed that writing is generally regarded as a difficult subject for the students. Since writing is the productive skill in the written mode which is more complicated and seems to be the 
hardest of the skill, even for native speakers of a language, since it involves not just a graphic representation of speech, but the development and presentation of thoughts in a structured way (Aydogan \&Akbarov, 2014).

Furthermore, the students of ninth grade in Islamic Boarding School Al-Munawwaroh Bangko also had the difficulties of writing. The researcher thought that there are some problems, which caused the students' difficulties in writing. First, students have lack of motivation to write and it could be seen based on the observations that had been done by the researcher three times in IBSA (Islamic Boarding School Al-Munawwaroh). The researcher found that the students did not do the task given to them, when the teacher asked them to write. The students felt difficult to explore or to express their ideas in written from; they always came to the teacher's seat and asked the teacher what they wanted to write. They did not try to find it by themselves. They were also difficult to arrange the words become a meaningful sentence and arrange the sentences become a paragraph. They were also afraid of making mistake in using tenses and the correct grammar; for instance, when they were asked to write the announcement. Finally, because of those effects, most of the student just copied the assignment of their friend or repeated the same ideas from the textbook. It means only a few students who had participation in writing class.

The second problem was students have lack of vocabulary, and the last was the teaching strategy used by the teacher is a common way. Based on the interview with English teachers; about the strategy in teaching that they used, the teachers said that they just use conventional strategy in teaching writing. The teachers just asked the students to write. The students' writing score proved the fact. Based on the information obtained from the English teacher, $60 \%$ of the students from 35 students or about 21 students achieved low score under the criteria minimum score (KKM) of writing that has been established before, namely 70 .

Based on the problems stated previously, it is necessary to solve those problems. The researcher is interested in using mind mapping to be a strategy in teaching. Regarding the experts opinions, mind-mapping strategy is one of the effective strategies in teaching writing. A mind map is considered a diagram used to represent the relationship of words, ideas, tasks, or other items connected to and arranged around a central key word or idea (Deshatty \& Mokashi, 2013). In addition, Buzan notes that mind mapping is made up of words, colors, lines, and pictures. The main point of this strategy is putting one word in a center as the general idea from the writer's mind. This enables students to write down many words specifically from the he previous general word. It is thus an effective tool to aid in studying and organizing information as well as writing. It helps 
students to associate ideas, promote creative thinking, and establish meaningful connections among ideas (Buzan, 2010).

A Mind Map is a visual diagram used to record and organize information in a way that the brain finds captivating and easy to process. Thoughts, ideas or facts are laid out around a central theme so that a person or in this case, the students can clearly 'see' their flow across different levels. Unlike linear methods for recording information, a Mind Map uses more lines, symbols, key words, color and images all according to simple, brainfriendly concepts rather than a written text (Arulselvi, 2017). Moreover, mind maps may be used as an effective technique in the process of learningteaching as a form of note taking which has significant differences from traditional note taking form (Erdem, 2017). In writing process, as a graphic visual aid, mind maps demonstrate a writer's ideas towards a certain topic as well as how the ideas are connected to each other (Sturm \& RankinErickson) in (Zhang, 2018).

This strategy is considered helpful for students as it proved to activate students' writing performance as study done by Al- Zyoud \& Al Jamal, \& Baniabdelrahman (2017) who confirmed that the mind mapping strategy improved students' writing performance in test scores. This strategy is claimed to make the writing process as meaningful as possible where students can express their thoughts appropriately. Mind mapping strategy is related to enabling students to think while using pictures and images demonstrated to them.

Then, the current study Zhang (2018) who explored the effects of mind mapping at the pre-writing stage on EFL writing revealed that explicit instruction of mind mapping could help Chinese EFL learners improve their argumentative writing performance, especially on contents and organization. In writing instruction, the mind maps can be used as a tool to help learners approach the topic from the meaning-focused perspective by associating it with their prior knowledge, thus it effectively lowers the cognitive requirement for foreign language learners. furthermore, the study done by (Yunus \& Chien, 2016) revealed that majority of the students had positive perceptions of the use of mind mapping strategy in enhancing their writing skills. The students in this research perceive mind mapping technique as an effective strategy in helping them to write and as a result, the mind mapping technique seemed to be an effective tool to help students in planning and organizing their writing by encouraging students to gain a comprehensive understanding of the writing topics. It can be concluded that mind mapping can be implemented in teaching writing.

Thus, based on the usefulness of mind mapping, the researcher was interested in conducting research in teaching writing by using mind mapping at the ninth grade students of Islamic Boarding School Al- 
Munawwaroh Bangko. The objectives of this research were to describe the teaching process by using mind-mapping technique, to describe the students' writing skill taught by using mind-mapping technique.

Mind mapping is also recognized as a brainstorming technique that can be used by a cognitive tool by the teacher in arranging and organizing the information of a new topic that will be presented and studied to the students (Hillar, 2012). It is a great tool for summarizing information and group events that are related to each other. In addition, mind mapping is the combination of colors, images and also the diagram that reveals the connections between the items of learned material hierarchically. In summary, he says that mind mapping is a teaching strategy that asks students to draw a diagram to be used to outline information represented by pictures and colors (Eppler, 2006).

Related to some previous opinions, the researcher concluded that mind mapping is the teaching strategy that enables students to recall words as many as they can or to brainstorm their words. In addition, this strategy also enables the students to make the relation of ideas, and encourages them to group certain ideas together.

Making mind mapping is simple (Buzan, 2005). The students could follow five following steps: first, use blank sheet unlined paper and some colored pens, and place sideways. Next, draw a picture in the middle of the paper/ page about the main topic/subject. Then, draw same thick curve, connected lines from the picture in the middle of the paper, one for each of the main ideas about the subject/topic. The central branch should represent the main sub topic. After that, give the name of these ideas by underlining and then, draw a little picture of each-to show as they are as key words, show their importance. Finally, from each idea, draw others connected lines, spreading like the branches of the tree, and then add thoughts on each of these ideas. Related to this theory, it can be concluded that the students will be easy to make mind mapping.

Uusen in Westwood (2008) states that writing is a complex and demanding skill. Writing is the way to express ideas in written form using letters, words, art or media, and it requires mental process in order to express the ideas. In addition, as Weigle (2002) notes writing is as an activity that require a context to achieve a certain purpose and for intended audience. Writing is also a cognitive activity. Weigle discusses the complex cognitive process, or mental activities, involved in writing, the source of knowledge writers draw upon in writing and other factors that influence the writing process. In addition, Sturn and Koppenhaver in Westwood (2008) inform that composing for writing includes the complex thinking that requires integrated multiple components such as the topic or theme, 
dictions, organization, aims, audience, clarity, sequence, cohesion and transcriptions.

Related to some experts' opinions above, it can be summarized that writing is a complex skill. There are many components that are needed and considered when the students or people write, because of that components, it make writing is regarded as the difficult skills to be learned by the students. Based on the syllabus of junior high school in School Based Curriculum, especially at the ninth grade of the first semester, in writing, the students are expected to be able to express the meaning in short written functional text and simple essay in forms of procedure and report to interact with the surroundings. Therefore, in this research, the researcher used mind mapping strategy in teaching writing in procedure text.

Knapp \& Watkins (2005) states procedural text is text that concerns with telling someone how to do something. Similarly, Yvonne, (1998) explains that procedures give the reader instruction about how to do or make something and the purpose of procedure is to tell how to do something. In summary, procedure text is a text that shows the reader how to do or to make something through the sequence of actions or steps.

Procedural text always begins with the goal of the text which is usually stated as heading(Knapp \& Watkins, 2005). After this stage, a set of ingredients or the materials required to complete the test orderly. The text then provides a sequence of steps specifying how the goal is to be achieved; the illustrations or the diagrams to assess the reader with the test at hand may accompany the steps.

Similarly, (Kistono, Esti Tri., \& Tupan, 2007) explain the features of procedure as the following: first, aim; the opening statement states what has to be done in order for the procedure to be successful. Second, materials; this is a listing of all the materials needed to carry out the procedures effectively. The last, method; the method is presented in a series of steps or things to do. Based on the explanation above, the summary that can be drawn is the procedure text generally consists of a goal, materials and the series of steps.

\section{METHODS}

\section{Participants of the Study}

Classroom Action Research (CAR) was employed in this research. The researcher chose classroom action research because the researcher wanted to make a change in the class and to solve the problems found. As (Mac Naughton \& Hughes, 2008) note that action research is a cyclical process of "think-do-think" to research and to create a change. They also state that action research begins with hope, dreams, and desires. It means that an action researcher hopes he/she can create a shift, dreams a better world and desires to make different. 
The researcher conducted this research in three cycles and there were three meetings for each cycle. As stated previously, the students had problem in writing and the teachers just used common way in teaching, so in this occasion, the researcher is interested to overcome the problems; the researcher as a teacher wanted to improve students' writing by applying mind mapping strategy in teaching. The research took place at IBSA Bangko. The participants were the students of the ninth grade especially ninth grade A. There were 23 female students in this class. The researcher chose this class because between two classes of the ninth grade, this class has problems in writing. Then, the object of the research was English teaching and learning process of writing subject. The material taught was procedure paragraph related to the syllabus at the school.

\section{Instruments}

The researcher used observation, field note, and test. For qualitative data, the researcher used observation sheet (for teacher and students) and field note, while for collecting quantitative data, the instruments used was writing test. The researcher employed writing test in third meeting for each cycle; the researcher asked the students to write or compose the paragraph based on the given topic and related to their mind map. After the researcher got the data from observation sheet, field note, written test, and then the researcher analyzed the data.

\section{Data Analysis Procedures}

The researcher got qualitative data from observation and field note. In analyzing qualitative data, there were five steps done by the researcher. It was adapted from (Gay \& Airaisian, 2000). The researcher received the quantitative data from writing test. For writing test, the researcher used two scorers/ inter rater scorer to check students' writing result. Students' paragraph will be analyzed to find students' ability in writing paragraph by using the scoring rubric that is adapted from (Cohen, 1994).

After calculating students' score, to determine their achievement, the score was compared to Minimum Score Criteria (KKM) of writing, which was 70. Based on that criterion, it could be concluded that if the students got the score between 0 until 69, it means that they were in incomplete criterion or they did not reach the KKM, but if they got the score between 70 until 100, it means that they were in complete criterion or they reached the KKM.

\section{FINDINGS}

\section{The First Cycle}

First cycle had been done on August 3rd for the first meeting, August $05^{\text {th }}$ for the second meeting and the last meeting on August $08^{\text {th }}$.The result of the 
first cycle; observation and the test, revealed that students had difficulties in choosing appropriate words related to procedure text. They also had difficulties in using correct grammar; imperative sentences and action verbs used in procedure text, spelling and mechanic in writing. They ignored capital letter and punctuation usage in their paragraph writing.

Furthermore, related to their mind map, the students did not follow the steps in making mind map well. They wrote sentences in their mind map not the key words, they also did not use the colored pen or markers. It seemed they had not understood yet about how to make mind mapping. In addition, related to the questionnaire data, the result showed that the students have high response in using of mind mapping in teaching and learning writing. Next, related to students score in writing test (the students who came to the class were 20 students); the data showed that the classical completeness average of students' score in writing test was $40 \%$. The data showed that those average score were under the classical completeness criterion that was $70 \%$. The data about the students' score in writing test, for more detail could be seen in the following table:

Table 1.Students' Writing Score Criteria in the First Cycle

\begin{tabular}{ccc}
\hline Students' score & Frequency & Criteria \\
\hline $0-69$ & 8 & Incomplete \\
$70-100$ & 12 & Complete \\
\hline
\end{tabular}

Based on the findings of the cycle one, the researcher considered that it was necessary to revise the plan for the next cycle. The researcher decided to divide the students into several groups and add more explanation and example about the vocabularies related to the procedure text, add the explanation about imperative sentence and action verbs used. Then, the researcher was suggested to add the explanation about mind map, and remind the students to bring their colored pen or markers. Based on those phenomena, the researcher decided to conduct the cycle two

\section{The Second Cycle}

According to the result of cycle two, it was found that there were improvements of students' activeness in the class. They were more active than the first cycle. Then, the students' response toward the use of mind mapping has improved too, from 55\% students who have high response in cycle one become $57.14 \%$ in cycle one. Furthermore, related to their mind map, the students had follow the rules in making the mind map, so their mind map in this cycle more colorful than the first cycle. Next, related to students' score in writing test (the students who followed the test were 21 students); the data showed that the average completeness of students' score in writing test was $76.20 \%$. The details information was presented in the following table: 
Yelni Erniyati

Table.2 Students' Writing Score Criteria in the Second Cycle

\begin{tabular}{ccc}
\hline Students' score & Frequency & Criteria \\
\hline $0-69$ & 5 & Incomplete \\
$70-100$ & 16 & Complete
\end{tabular}

Based on tabel 2, it could be concluded that those average score were above the classical completeness criterion that was 70\%.It meant that there were improvements in the cycle one. However, the data also showed that there were 5 students who have problems in writing; organization, content, vocabulary, grammar and mechanic. The researcher decided to conduct cycle two that would use picture and areal object in applying mind-mapping technique in teaching the students.

\section{The Third Cycle}

In this cycle, the researcher used the pictures and a real object in applying mind mapping. There were 18 students came to the class and 4 students did not come. The students were asked to write a procedure text based on their own mind map. The researcher reminded them to pay attention to the vocabulary, grammar and mechanic used in their writing. The result of the third cycle revealed that students' average score in classical completeness was $77.78 \%$ with the total students who got the completeness criterion were 14 students from 18 students who had attended the class on the day. Regarding to the writing aspects, the average score for each aspect was improved, although in this cycle, vocabulary and grammar aspects were lower than others aspects. The highest average was organization aspect and content aspect. It could be reported that students had understood about how to organize and state the idea clearly in their paragraph writing.

The researcher found that there were improvements from the first, the second cycle and the third cycle. It could be seen from the result of observation, field note, and writing test. Based on the completeness criterion maximum (70) and classical completeness criterion (70\%), the scores that had been achieved in the first meeting until the third meeting of students' writing test, it were achieved those criteria scores compared with the students' preliminary data. Although in third cycle there were four students, who were in incomplete criterion for writing test, but as a whole, their average score had achieved the completeness criterion that established before, and the researcher decided to finish the research.

\section{DISCUSSION}

Regarding to the previous relevant research, this research has the same result although this research done in different school, class, subjects and materials. After conducting the classroom action research, the researcher found that there were enhancements of students' condition and achievement 
in writing compared with their condition and achievement before the researcher conducted the research. Regarding all cycles that had been done, the first cycle was the difficult one, because in the first cycle the researcher tried to use mind mapping technique for the first time, and mind mapping technique was a new technique for the students and the teacher was also new for the students, so they have to adapt with those conditions.

\section{The Researcher Enhanced Students' Writing Using Mind mapping}

After conducting the research, the researcher found that there were improvements of students' writing skill. Before doing the research, she obtained the information and the data from the English teacher that the students have less vocabulary and it made them were difficult to explore their ideas in written form; $60 \%$ or around 15 students from 23 students got the score under the completeness criterion score that was 70.

Then, the researcher tried to solve the problems by applying mindmapping technique in teaching writing. The students were easy in getting the words when they were asked to make their own mind mapping related the topic given. Moreover, regarding to students' writing skill, there were improvement too. In the first cycle, the students who were in incomplete criterion were eight students with the classical completeness percentage were $40 \%$. Additionally, based on the writing aspects, in this cycle, students have problems more in vocabulary and mechanics with the average score was 2.85 for both. Moreover, the students got the highest average score in organization criterion, namely was 3.80 . It could be concluded that the students have understood about how to organize their writing in procedure paragraph. Then, at the second cycle, the students who were in complete criterion were 15 students with the classical completeness percentage $71.43 \%$. Related to writing aspects, in this cycle, students' vocabularies were improved; the students had improvement in choosing words. And the students had a problem in grammar aspect with the average score 3.05.

In cycle two, students' average score in classical completeness was $77.78 \%$ with the total students who got the completeness criterion were 14 students from 18 students who had attended the class on the day. The average score for each aspect was improved, although in this cycle, vocabulary and grammar aspects were lower than others. The highest average was organization aspect and it was followed by content aspect. It could be reported that students had understood about how to organize and state the idea clearly in their paragraph writing. The improvement of students' writing from the first cycle to the second cycle was $31.43 \%$ and from the second cycle to the last cycle was $6.35 \%$.

Those writing results proved that mind mapping technique could be used in teaching writing because mind mapping could assist students in 
organizing and generating more ideas. This result is also proved by AlZyoud \& Al Jamal, D. Baniabdelrahman (2017) confirmed that the mind mapping strategy improved students' writing performance in test scores. This strategy is considered helpful for students as it proved to activate students' writing performance. This strategy is claimed to make the writing process as meaningful as possible where students can express their thoughts appropriately.

In addition, finding from the present study by Zhang (2018) explored the effects of mind mapping at the pre-writing stage on EFL writing. The findings revealed that explicit instruction of mind mapping could help Chinese EFL learners improve their argumentative writing performance, especially on contents and organization. By corresponding to the findings of this research with those previous studies that have been done by some researchers, it can be concluded that mind map could be used in teaching and enhancing students' writing skill, and in this research especially at ninth grade of Islamic Boarding School Al-Munawwaroh Bangko.

\section{The Researcher Changed Classroom Condition Using Mind Mapping}

As stated in the previous background of this research, before the researcher conducted the research in the class, the students did not try to answer their exercise by themselves; they always come to the teacher's seat to get the answer. They forgot the words that had been taught to them, the teaching seemed monotonous because just the teacher who was active in the learning process. They felt boring so they kept silent when the teacher asked them. Moreover, when they were asked to write; they just copied their friend assignment.

Then, after the researcher conducted the research, it was a changing in the classroom condition when the teaching and learning process happen. The students seemed interesting and motivating because the technique was something new for them although, for the first time the students still ashamed and awkward to the teacher, because the teacher is new also for them. Students were more focus, active and enthusiastic in participating, recalling and brainstorming the words. They tried to answer the teacher's questions.

This result was proved by the studies that have been done by some researchers. Firstly, the study conducted by Rafii (2017). The study was carried out with the objective to investigate the improvement in students' motivation in writing descriptive texts by using mind mapping technique. The study affirmed that the use of mind mapping technique not only developed writing skills but also increased the level of motivation in students. 
Wangmo \& Chalermnirundorn (2018) also found that students were observed participating actively, responding promptly to the given questions and asking questions to clear their doubts. Students exhibited the learning satisfaction in writing essays through mind mapping technique and they realized that writing could be easier and fun with mind mapping technique to guide them. Therefore, mind-mapping technique had motivated them to perceive writing with positive attitude and enthusiasm. In conclusion, mind mapping technique could change the teaching and learning process condition.

\section{CONCLUSION AND SUGGESTION}

Some conclusions are drawn. First, teaching and learning process by using mind mapping was more interesting; the students gave more participation in the class in recalling the words. Second, there are enhancements of students' writing after the teacher taught them by using mind-mapping technique. It can be seen from the improvements of students' score from the preliminary data before the researcher conducted until the third cycle done.

According to the research results, there will be some suggestions for the following people: (1) Teacher; the teacher can apply mind mapping technique in teaching writing, not only in procedure text but also to others materials. (2) Students; the students can apply mind mapping in enhancing their vocabulary and writing, and in recalling the vocabularies related to the materials, not only in procedure text but also another material. (3) Researcher and other researchers; the researcher and other researchers can do another research by applying mind mapping technique not only in writing skill but also to another language skill, and not only in procedure text but also in other kinds of texts of materials.

\section{REFERENCES}

Al- Zyoud, A. A., \& Al Jamal, D. Baniabdelrahman, A. (2017). Mind Mapping and Students' Writing Performance. Arab World English Journal, 8(4).

Aydogan, H., \& Akbarov, A. A. (2014). The Four Basic Language Skills, Whole Language \& Integrated Skill Approach in Mainstream University Classrooms in Turkey. Mediterranean Journal of Social Sciences, 5(9), 672-680

Arulselvi, E. (2017). Mind Maps in Classroom Teaching and Learning. The Excellence in Education Journal, 6(2).

Buzan, T. (2005). Mind Maps for Kids: an Introduction the Shortcut to Success at School. UK: Thorsons.

Buzan, T. (2010). Buku Pintar Mind Mapping Untuk Anak. Jakarta: PT Gramedia Pustaka Utama. 
Yelni Erniyati

Cohen, A. . (1994). Assessing Language Ability in the Classroom (2nd ed.). Boston: Heinle and Heinle Publishers.

Deshatty, D. D., \& Mokashi, V. (2013). Mind Maps as a Learning Tool in Anatomy. International Journal of Anatomy and Research, 1, 100-103.

Eppler, M. J. (2006). A Comparison between Concepts Maps, Mind Maps, Conceptual Diagrams, And Visual Metaphors as Complementary Tools for Knowledge Construction and Sharing. Information Visualization.

Erdem, A. (2017). Mind Maps as a Lifelong Learning Tool. Universal Journal of Educational Research, 5(12A), 1-7. https://doi.org/10.13189/ujer.2017.051301

Gay, L. ., \& Airaisian, P. (2000). Educational Research: Competencies for Analysis and Application. Ohio: Prentice -Hall, Inc.

Hillar, S. P. (2012). Mind Mapping With Free Mind. Brimingham- Mumbai: Packt Publishing.

Kistono, A., Esti Tri., I., \& Tupan, A. (2007). The Bridge English Competence for SMP Grade IX. Jakarta: Yudhistira.

Knapp, P., \& Watkins, M. (2005). Genre, Text, Grammar: Technologies for Teaching and Assessing Writing. Australia: University of New South Wales Press ltd.

Linse, C., \& Nunan, D. (2005). Practical English Language Teaching: Young Learners. New York: McGraw-Hill.

Mac Naughton, G., \& Hughes, P. (2008). Doing Action Research in Early Childhood Studies: A Step by Step Guide (O. U. Press, Ed.). England.

Rafii, A. (2017). Improving students' motivation in writing descriptive texts by using mind mapping. ELT Echo: The Journal of English Language Teaching in Foreign Language Context, 2(2), 147-157.

Wangmo, K., \& Chalermnirundorn, N. (2018). The Use of Mind Mapping Technique to Enhance Writing Skills of Grade Four Bhutanese Students. St. Theresa. Journal of Humanities and Social Sciences, 4(2).

Weigle, S. C. (2002). Assessing Writing. UK: Cambridge University Press.

Westwood, P. (2008). What Teachers Need to Know about Reading and Writing Difficulties. Autralia: Acer Press.

Yunus, M. M., \& Chien, C. H. (2016). The Use of Mind Mapping Strategy in Malaysian University English Test (MUET) Writing. Creative Education, 7(4), 619-626.

Yvonne. (1998). English K-6 Syllabus: Text Types. Sydney: Desktop Publishing

Zhang, Y. (2018). A Contrastive Study on the Application of Mind Maps in Argumentative Writing Instruction for EFL Learners. Canadian Center of Science and Education: English Language Teaching, 11(12). 